\title{
Upaya yang dilakukan oleh guru PPKn dalam menanggulangi tawuran pelajar di SMK Bina Karya 1 Kabupaten Karawang
}

\author{
Muhamad Jawir Ripa'l $\left.\right|^{\mathrm{a}, 1^{*}}$, Yogi Nugraha ${ }^{\mathrm{b}, 2}$, Aris Riswandi Sanusic, 3 \\ abc Pendidikan Pancasila dan Kewarganegaraan, Universitas Buana Perjuangan Karawang, Indonesia \\ ${ }^{1}$ pk15.muhamadripai@mhs.ubp.karawang.ac.id \\ *korespodensi penulis
}

\section{ABSTRAK}

Penelitian ini bertujuan mengetahui upaya yang dilakukan oleh pihak Guru PPKn dalam menanggulangi tawuran antara sekolah di SMK Bina Karya 1 Kabupaten Karawang. Penelitian ini menggunakan pendekatan kualitatif dengan metode deskriptif. Subjek penelitian ini adalah guru Pendidikan Pancasila dan Kewarganegaraan di SMK Bina Karya I Karawang. Tenknik pengumpulan data menggunakan wawancara, observasi, dan studi dokumentasi Teknik analisis data menggunakan triangulasi data. Hasil penelitian menunjukan bahwa upaya yang dilakukan guru dalam menanggulangi tawuran pelajar yaitu melakukan pendekatan secara emosional. Pendekatan emosional dilakukan dengan cara memberikan perlakuan yang baik kepada pelajar sehingga pelajar memiliki rasa nyaman, aman dan mampu terbuka kepada guru.

\section{ABSTRACT}

This study aims to determine the efforts made by the PPKn teacher in overcoming brawls between schools at SMK Bina Karya 1, Karawang Regency. This research uses a qualitative approach with descriptive methods. The subject of this research is the Civic Education teacher at SMK Bina Karya I Karawang. Data collection techniques used interviews, observation, and documentation studies. Data analysis techniques used data triangulation. The results showed that the efforts made by the teacher in overcoming student brawls were emotional approaches. Emotional approach is done by giving good treatment to students so that students feel comfortable, safe and able to open up to the teacher.

\author{
Informasi Artikel \\ Diterima : 2 januari 2020 \\ Disetujui: 25 januari 2020
}

Kata kunci:

Penanggulangan Tawuran Pelajar, Upaya guru PPKn

\section{Article's Information: \\ Received: 2 Januari 2020 \\ Accepted: 25 Januari 2020}

Keywords:

Student Fighting Management, PPKn teacher efforts

\section{Pendahuluan}

Seiring perkembangannya, remaja akan mengalami banyak perubahan yang signifikan, perubahan tersebut bisa dari segi fisik, kognitif, sosial dan tingkat emosionalnya yang labil (Sarwono, 2016). Perubahan yang terjadi pada masa remaja cukup signifikan sehingga rentan melakukan perilaku yag menyimpang. Adapun perilaku-perilaku penyimpangan yang biasa dilakukan remaja diantaranya adalah tawuran, bullying, kekerasan, perilaku seksual, dan pemakaian obat-obatan terlarang.

Tindakan tawuran yang terjadi antarpelajar memiliki beberapa faktor penyebab diantaranya adalah faktor internal yaitu dari dalam dan faktor eksternal yaitu dari luar. Terjadinya tawuran disebebkan lingkungan yang kurang kondusif baik internal ataupun eksternal. Faktor internal merupakan faktor kepribadian remaja yang kurang baik sehingga dapat memicu terjadinya kenakalan-kenakalan atau perilaku menyimpang yang melanggar norma-norma yang berlaku di masyarakat atau keluarga. Hal tersebut menyebabkan dampak negatif baik bagi sendiri ataupun orang lain yang mengalami kerugian secara materi ataupun nonmateri (Setyawan, 2014:3). Selain faktor internal yang berasal dari dalam diri remaja yang dapat menyebabkan terjadinya tawuran adalah faktor eksternal atau faktor dari luar seperti keluarga, lingkungan sekolah dan lingkungan sekitar (Dianlestari, 2015). Hal tersebut menunjukkan bahwa kepribadian siswa dan lingkungan yang 
kurang kondusif merupakan faktor yang sangat mempengaruhi terjadinya perilaku-perilaku menyimpang seperti tawuran yang dapat menyebabkan keresahan dan kerugian baik bagi diri sendiri ataupun orang lain.

Tawuran pelajar merupakan istilah yang sudah tidak asing didengar. Tawuran pelajar berasal dari dua suku kata yaitu tawur dan pelajar. Dalam Kamus Besar Bahasa Indonesia tawur merupakan perkelahian beramai-ramai, perkelahian masal, perkelahian yang tiba-tiba terjadi antara kedua pihak yang berselisih. Sehingga dapat diartikan tawuran pelajar merupakan perkelahian yang dilakukan oleh sekelompk orang yang sedang belajar. Dampak yang dirasakan akibat tawuran bukan hanya diraskan oleh para pelajar yang terlibat tawuran melainkan masyarakat pun merasakan akibat dari terjadinya tawuran sehingga tawuran merupakan hal yang perlu diperhatikan karena memberi dampak buruk bagi banyak pihak baik dari segi ekonomi, sosial ataupun budaya (Aprilia \& Indrijati, 2014). Sehingga tawuran merupakan fenomena yang perlu sangat diperhatikan karena dampak dari tawuran dirasakan oleh banyak pihak baik pelajar itu sendiri ataupun masyarakat sekitar.

Permasalahan tawuran bukanlah hal baru diberbagai kota di Indonesia. Tawuran sudah banyak terjadi di tengah-tengah masyarakat baik masyarakat kota-kota besar ataupun kota-kota kecil. Sebagai contoh kasus perkelahian antar pelajar yang ada di kabupaten Karawang khususnya di SMK bina karya 1 . Seringnya perkelahian terjadi antar pelajar yang melibatkan siswa SMK Bina Karya 1. Dua kelmpok pelajar dari SMK J dan SMK Bina Karya terlibat tawuran. Dua kelompok tersebut terlibat saling serang menggunakan benda tajam. Peristiwa terjadi di jalan Interchange Karawang Barat pada kamis (16/8) petang sekitar pukul 17.30 WIB. Perkelahian tersebut menyebabkan seorang pelejar terkena sebatan samurai dan mengalami luka di daerah pelipis kanan, leher dan punggung sekitar 38 jahitan. Berdasarkan kesaksian, tawuran antar pelajar di wilayah tersebut kerap terjadi bahkan saat jam pelajaran berlangsung. Banyak diantara warga yang mengaku geram dengan aksi generasi muda yang terpelajar karena dianggap meresahkan (Merdeka.com, 2018). Adapun berdasarkan hasil wawancara awal dengan bagian kesiswaan di SMK Bina Karya I Karawang menunjukkan bahwa pada tawuran terakhir di sekolah tersebut terjadi pada awal bulan Juli 2019 dengan seorang siswa terkena benda tajam.

\section{Metode}

Pada penelitian ini penulis menggunakan pendekatan kualitatif, oleh karena itu hasil penelitian ini bersifat analisis-deskriptif yakni, berupa kata-kata tertulis atau lisan dari perilaku yang dianalisi terutama terkait dengan bagaimana upaya yang dilakukan oleh pihak Guru PPKn dalam menanggulangi tawuran pelajar antara sekolah di SMK Bina Karya 1 Kabupaten Karawang.

Subjek penelitian ini adalah guru Pendidikan Pancasila dan Kewarganegaraan di SMK Bina Karya I Karawang. Objek penelitian peneliti yaitu mengenai upaya yang dilakukan oleh pihak Guru PPKn dalam menanggulangi tawuran pelajar antara sekolah di SMK Bina Karya 1 Kabupaten Karawang.

Teknik pengumpulan data pada penelitian ini terdiri dari ; wawancara, observasi, dan studi dokumentasi. Teknik analisis penelitian ini melalui cara wawancara, observasi, studi dokumentasi, dan triangulasi. Analisis data dalam penelitian kualitatif dilakukan sejak sebelum memasuki lapangan, selama di lapangan dan setelah selesai di lapangan, lalu melakukan reduction (reduksi data), display (penyajian data), dan Conclusion drawing/verification.

\section{Hasil dan Pembahasan}

Kasus tawuran yang terjadi adalah masalah pelanggaran terhadap kebijakan hukum. Maka pihak sekolah dan guru PPKn menyerahkan sepenuhnya hukuman kepada pihak yang berwenang untuk menangani kasus tawuran yang melanggar hukum. 
Penggunaan upaya hukum pidana sebagai ultimum remedium, dimaksudkan sebagai salah satu upaya untuk mengatasi masalah sosial, termasuk bidang kebijakan penegakan hukum, sebagai upaya yang rasional untuk mencapan kesejahteraan masyarakat (Nuraeny, 2011).

Selain itu, guru PPKn juga memberikan penanganan khusus kepada pelajar

SMK Bina Karya I Karawang sebagai upaya penanggulangan dari banyaknya kasus-kasus tawuran yang melibatkan pelajar SMK Bina Karya I Karawang. Upaya tersebut yaitu melakukan pendekatan secara emosional. Pendekatan emosional dilakukan dengan cara memberikan perlakuan yang baik kepada pelajar sehingga pelajar memiliki rasa nyaman, aman dan mampu terbuka kepada guru. Sebagaimana yang dikemukakan oleh Nuraeny (2011) :

Penanggulangan pidana selain menggunakan sarana penal dan non penal, dapat juga dilakukan dengan pendekatan nilai dalam melakukan pembuatan keputusan, misalnya melalui pendekatan lingkungan sekolah, lingkungan keluarga, masyarakat dan sosial lainnya. Pengenaan sarana dengan nilai dapat dilakukan sebagai perwujudan dari reaksi masyarakat, yaitu dengan cara pendekatan kerja sama antara pemerintah dan masyarakat dalam rangka mewujudkan sistem hukum yang baik, dan menumbuh kembangkan peran serta masyarakat dalam kegiatan pencegahan terhadap tindak pidana (Nuraeny, 2011)

Dengan demikian, penanggulangan yng dilakukan oleh guru PPKN sebagai upaya menanggulangi tawuran adalah dengan menyerahkan kepada kepolisian untuk memberikan hukum pidana sesuai kebijakan hukum yang berlaku dan melakukan pendekatan di lingkungan sekolah, adapun pendekatan yang dilakukan adalah mengacu pada sila yang pertama yaitu nilai-nilai yang berdasar pada ketuhanan untuk memperbaiki moralitas siswa. Selain itu guru juga berusaha menerapkan nilai-nilai pancasila dan kewarganegaran untuk membentuk karakter yang baik.

\section{Simpulan}

Tawuran pelajar di SMK Bina Karya I Karawang merupakan fenomena yang seringkali terjadi. Oleh karena itu, pihak sekolah memiliki komitmen khusus sebagai upaya penanggulangan jika terjadi tawuran pelajar di SMK Bina Karya I Karawang. Adapun komitmen tersebut ialah apabila pelajar terlibat dalam tawuran dan membawa benda tajam maka pelajar langsung dikeluarkan dari sekolah tanpa kecuali. Pada tahun 2018, pihak sekolah sudah mengeluarkan sekitar 10 pelajar yang terlibat tawuran dengan membawa benda tajam. Apabila pelajar yang mengikuti tawuran masih dalam tahap termaafkan maka sekolah memberikan pelajar tersebut kelas binaan selama satu bulan disetiap pergantian tahun ajaran. Selain itu, jika pelajar terlibat dalam tawuran dan terkena benda tajam lalu terluka maka pihak sekolah berusaha untuk menanganinya terlebih dahulu dengan cepat dan setelah itu diberlakukan konsekuensi hukuman sesuai dengan pelanggaran yang dilakukan. Selain itu, guru PPKn juga berusaha ikut andil untuk melakukan konfirmasi kejadian perkara tawuran dengan pihak sekolah yang bersangkutan dan bertanggung jawab secara bijaksana.

Pendekatan emosional juga sangat penting bagi guru PPKn untuk membangun rasa kepatuhan terhadap peraturan dan guru. Dengan adanya kelekatan emosional pelajar menjadi lebih patuh dan terbuka kepada guru. Selain itu, selalu bekerjasama dengan guru agama dan pihak sekolah untuk menjalankan peraturan yang berlaku di sekolah. Selain itu juga bekerjasama dengan guru agama dan kesiswaan dalam menjalankan shalat dhuha berjamaah agar terus berjalan bahkan dengan banyaknya tawuran guru semakin ingin memperbanyak kegiatan-kegiatan keagamaan seperti kajian bulanan di sekolah yang akan dicanangkan sebagai program bulanan sekolah. Hal tersebut dilakukan untuk menanamkan kesadaran pelajar terutama dalam mendidik karakter pelajar SMK Bina Karya I Karawang. Dengan demikian, adanya komitmen tegas dari sekolah dan upaya pendekatan dari guru 
mampu menjadikan siswa memiliki rasa takut untuk melanggar peraturan seperti melakukan tawuran kembali

Guru PPKn bekerjasama dengan guru lain dan pihak sekolah selalu berusaha untuk mencari solusi untuk mengurangi tawuran. Salah satunya adalah pernah dengan menyediakan mobil jemputan agar sekolah diantar jemput sampai rumah. Namun, ternyata bukan mengurangi angka tawuran tetapi justru memicu kembali terjadinya tawuran karena pada saat itu mobil jemputan sekolah dilempari batu oleh SMK X sehingga menyebabkan kaca-kaca mobil pecah. Sehingga program antar jemput menggunakan mobil jemputan tidak dilanjutkan karena membahayakan. Sehingga sekolah menyimpulkan bahwa akomodasi bukan hal yang bisa mengurangi kasus-kasus tawuran dan hal yang paling penting adalah memberikan pendidikan moral kepada siswa-siswi sekolah baik secara agama ataupun etika. Seperti yang telah dijelaskan program yang dibuat oleh sekolah adalah program shalat dhuha berjamaah setiap hari selasa dan rabu.

Hasilnya memang belum maksimal tetapi setidaknya pihak sekolah berusaha memberikan pendidikan moral baik secara agama ataupun etika.. Selain itu ada beberapa hal yang memang sudah dilakukan oleh pihak sekolah yaitu dengan mendatangkan dari pihak kepolisian dan pihak TNI untuk memberikan pembinaan tentang pendidikan karakter dan memebrikan materi tentang bahaya dampak tawuran antar sekolah, selain diberikan pemahaman tersebut pihak kepolisian dan TNI pun memberikan materi tentang sanksi - sanksi hokum, sanksi sosial kepada para siswa - siswi sekolah SMK Binakarya 1 agar siswa bisa mengetahui sanki tersebut yang diberikan kepada siswa - siswi apabila diantara mereka ada yang terlibat tawuran antar sekolah dan tujuannya diberikan pemahaman tersebut agar siswa - siswi bisa menghindari tawuran antar sekolah yang ada di kabupaten karawang. Berbagai upaya telah dilakukan oleh Pihak sekolah terutama guru PPKn yang terus melakukan penaggulangan - penaggulangan agar siswa - siswi di sekolah SMK binakarya 1 bisa terhindar dan tidak terlibat tawuran antar sekolah. Tentu saja hal ini bukan hanya tugas dari guru PPKn saja tetapi seluruh elemen yang berkaitan dengan bidang pendidikan, hukum dan pengelolaan pemberdayaan perempuan dan anak harus ikut berperan dalam penanggulangan tawuran antar sekolah yang ada di kabupaten karawang.

\section{Referensi}

Aly, Abdullah. 2011. Pendidikan Islam Multikultural di Pesantren. Yogyakarta: Pustaka Pelajar. Basri, Said. 2013. Fenomena tawuran antar pelajar dan konsekuensinya. Skripsi : Yogyakarta. Dianlestari, Meidayanti. 2015. Upaya Mengatasi Kenakalan Remaja : Tawuran di SMAN 4 Kabupaten Tangerang. Skripsi Semarang: Universitas Negeri Semarang.

Djamarah, Syaiful B. 2010. Guru dan Anak Didik dalam Interaksi Edukatif: Suatu Pendekatan Teoretis Psikologis. Jakarta: Rineka Cipta.

Hamalik, Oemar. 2009. Pendidikan Guru : Berdasarkan Pendekatan Kompetensi. Jakarta : PT. Bumi Aksara.

Idi, Abdullah. 2016. Pengembangan Kurikulum Teori \& Praktik. Jakarta : PT. Raja Grafindo Persada. Indrijati, Aprilia. 2014. Jurnal Vol. 3 No.01. Hubungan Antara Kecerdasan Emosi dengan perilaku Tawuran pada Remaja Laki-Laki yang Pernah Terlibat Tawuran di SMK "B" Jakarta. Jurnal Psikologi Pendidikan dan Perkembangan.

Kartono, Kartini. 2004. Patologi Sosial Jildi 1. Jakarta : Rajawali Pers.

Kirom, Askhabul. 2017. Jurnal Pendidikan Agama Islam. Volume 3 Nomor 1. Peran Guru Dan Peserta Didik Dalam Proses Pembelajaran Berbasis Multikultural.

Marlina. 2012. Peradilan Pidana Anak di Indonesia. Refika Aitama: Bandung.

Moleong, Lexy J. 2016. Metodologi Penelitian Kualitatif. Bandung : Remaja Rosdakarya.

Nafis, Muhammad M. 2011. IImu Pendidikan Islam. Yogyakarta: Teras. 
Novarianto, Wahyu. 2018. Upaya Penanggulangan Terjadinya Tawuran Antar Pelajar. Skripsi Bandar Lampung: Universitas Lampung.

Setyawan, Heru. 2014. Kebijakan Sekolah Dalam Mengatasi Tawuran Antar Pelajar di SMA Negeri 2 Ngaglik Sleman. Skripsi Yogyakarta: Universitas Negeri Yogyakarta.

Sagala, Syaiful. 2009. Kemampuan Profesional Guru dan Tenaga Kependidikan. Bandung: Alfabeta.

Sarwono. 2016. Psikologi Remja Edisi Revisi. Jakarta: Rajawali Pers.

Savitri, Sinaga, dkk. 2015. Kajian Kriminologi Terhadap Perilaku Tawuran Antar Pelajar Sekolah Menengah Atas di Kota Yogyakarta. Universitas Gadjah Mada: Yogyakarta.

Simen, Dewi A. 2013. Tinjauan Yuridis Terhadap Tindak Pidana Peekelahian Kelompok Yang Menyebabkan Kematian Oleh Geng Motor. Skripsi Makassar : Universitas Hasauddin.

Sudarsono, 2005. Kenakalan Remaja. Rineka Cipta: Jakarta.

Sugiyono. 2017. Metode penelitian kuantitatif, kualitatif, dan R\&D. Bandung : Alfabeta. 